14 二次元密闒空間内の感温液晶粒子に上る可視化実蜸

宇都宮大学工学部秋山光庯、㭪井勇、杉山均、池崎昭

Visualization Experiments on the Natural Convection in A Square Cavity

by Liquid Crystal Capsules

M.Akiyama, I.Urai, H.Sugiyama and A.Ikezaki

I sotherms of the natural convection in a square cavity have been obtained via an image processing which captured by means of the liquid crystal capsule method.

Also provided have been the results of the flow pattern plotted by pearl pigment particles. The results of isotherms and flow patterns have been compared with the solution for the same prameter with a simple Boussinesq approximation. The purpose of the present paper have been to comfirm the thermal field visualization by the liquid crystal capsule method and to provide a guideline in developing a new computer program code for such a flow field experimented.

1.はじめに

スーバーヌンビューターと数值解法の同時進展がきょう体内や室内の流動分布予湘を可 能にしつつある。数值解析は境界条件を变えるだけて、室内のみならず、建物周囲や物体

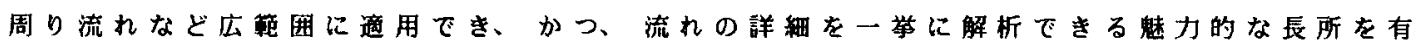
している。ここで扱う正方形密閉空間内自然対流については古くから数值解析が数多くな され、計算精度と計算コストの钼点における、解析手法改善のベンチマークテストとして 重要な地位を占めるに至っている。

しかしながら、流れ及び温度の初期及び境界条件や物性值の温度依存性などに関して、 数值解析は、実際の場を表現できるかと言う問題が、居流の場に於てすら吟味すべきこと として残されている。ここに模型実娩による数值解析の検討の必要性が考えられる。

本研究の特長は、次の通りである。（1）今日まての研究では流体には主として空気や水 が用いられて比較的熱物性の变化の小さいむのが扱われていたが、ここてはシリコン油を 用いることにより温度恢存性の効果を钼察する。（2）熟電対に上る壁温测定とあいまって、 感温液晶粒子による液温分布の可視化を行なう。（3）測定温度分布を画像処理し等温線を 得る。（4）パール顔料混入による流㲜镍察をする。（5）数值解析との比較検討を行なう。

\title{
2. 実験菬置及び方法
}

本実呀荘置は、二次元密開空間内の上下壁を断熱とし、侧壁に温度差加生じた場合の自 然対流温度分布を娭討したものである。Fig.1に供試空間を示す。寸法は $50 \mathrm{~mm} \times 50 \mathrm{~mm} \times 480$ mmで、二次元性を保つために然行き方向に断面一辺の9.6倍の長さか取られている。温度差

Department of Mechanical System Engineering, Utsunomiya University

2753 Ishi-cho, Utsunomiya City 321 , Japan 
を与える側壁は内側上り、銅板、シースヒー 夕、アクリル板の三重構造になっており、

自動温度調節器によりシースヒータの電源を ON/OFFさせ設定温度に保つ。アクリル板の 上下にはグラスウールを詰めて供試空間との 温度差を無くしていえ。測定断面は中心部分 であり、壁温测定のため、熱電対が上下壁に は9点、倒壁に㞲备1点、計 20 点埋め込まれて いる。可視化に際しては、测定断面の下壁に $5 \mathrm{~mm}$-10 m

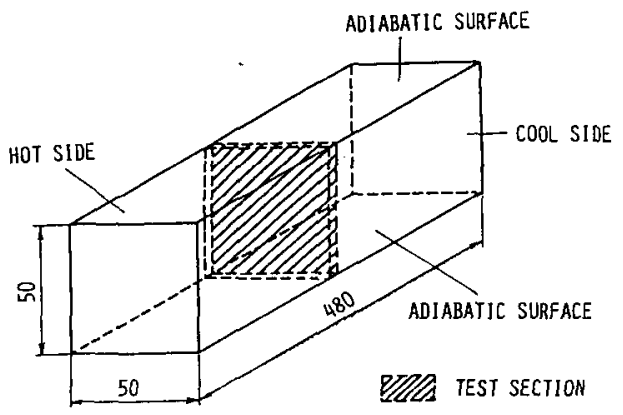

Fig.1 Test section エク夕一を光源とした。 温度分布の可視化飞壮 シリコンオイルに0.02 \% 感温液晶柆子、粒跡 線の可視化に纯バール 顔料をそれそれ混入し て使用した。

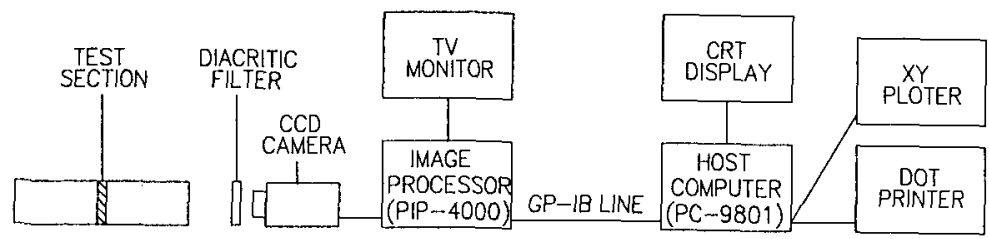

Fig.2 Schemalic diagram of image processing system

\section{3. 画像処理}

本実験て液晶の色を色分解光学フィルターで备成分に分解、計測し、それより温度を 算出するRGB法を試办た。これは温度分布をバターンとしてとられ、可視化された情報で定

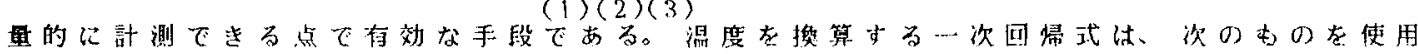

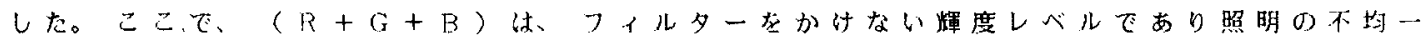
を補证するむのだ苛る。

$$
T=\frac{a R}{(R+G+B)}+\frac{b C}{(R+G+B)}+\frac{C B}{(R+G+B)}+d
$$

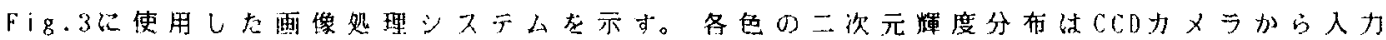

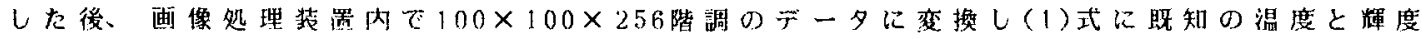
を代入し係数在決定し温度分布を求める。

\section{4. 結果と考察}

実鈋は、 $R_{a}=1.79 \times 10^{5}$ の条件で行なった。Fig.3に湾晶による温度分布写真を、をのR(

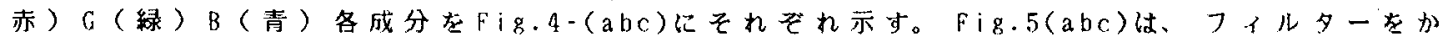

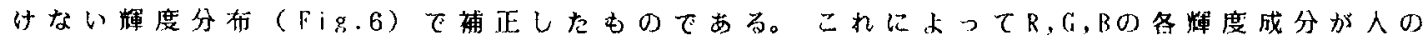
目に感する分布により近い屯のになっている。これらFig.5から求めた等温線をFig.7(a)に、

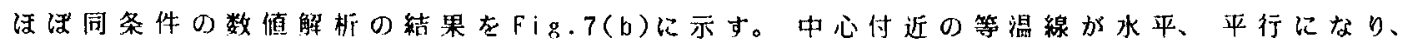
ほぼ一致しているが上下壁付近には違いがみられる。Fig.7(a)の温度分布は、上下壁が完 


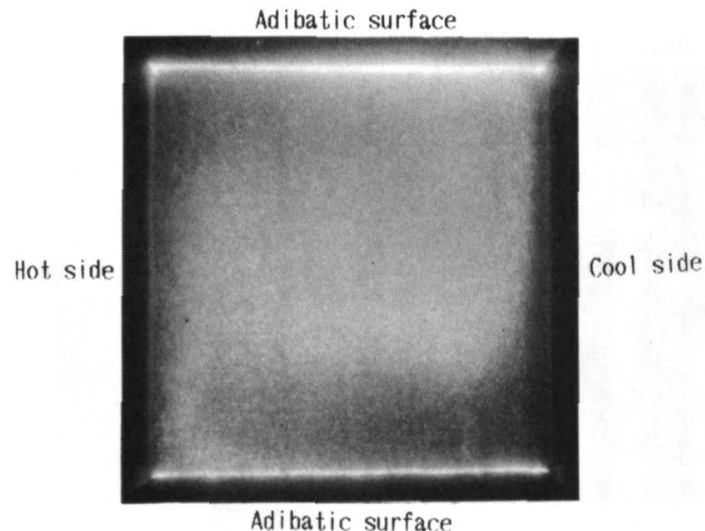

Fig.3 Photograph of liquid crystal

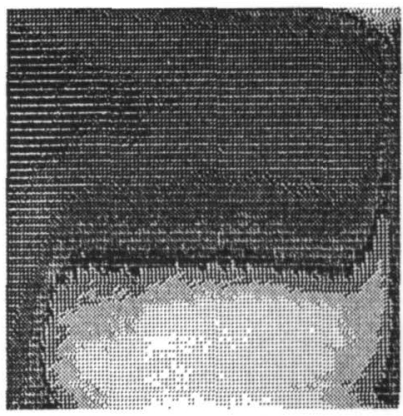

Fig.4 (a) Red intensity

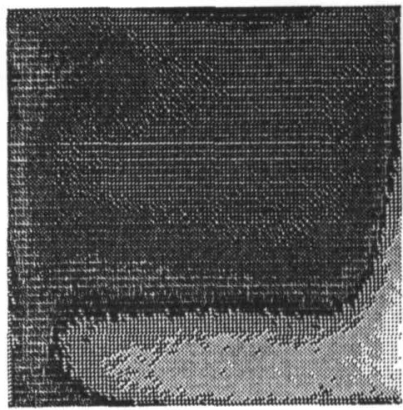

Fig.5 (a) Revised red intensity

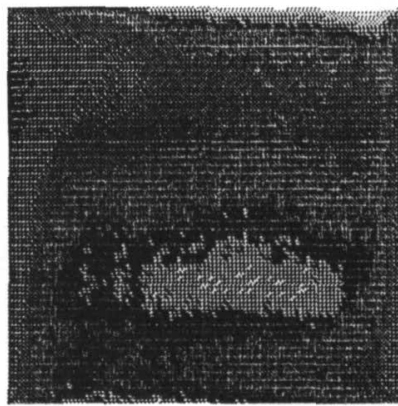

Fig.6 Intensity distribution

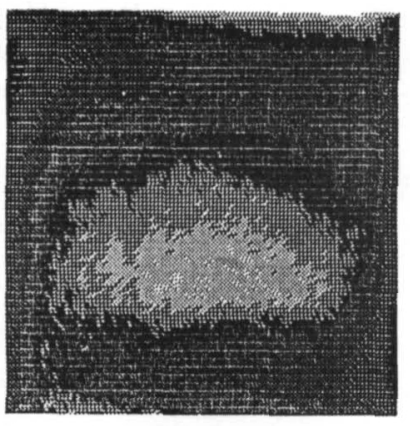

Fig.4 (b) Green intensity

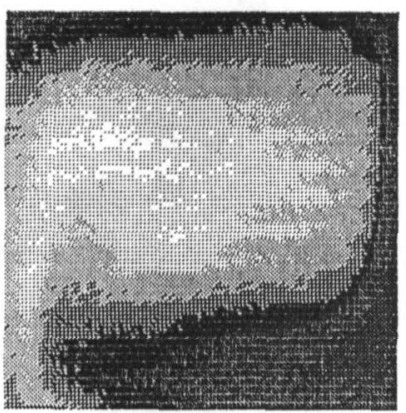

Fig.5 (b) Revised green intensity

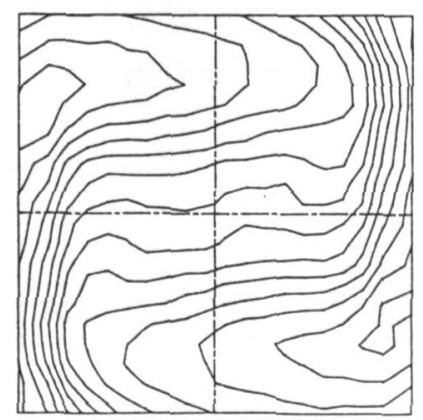

Fig.7 (a) Isotherms by RGB methor

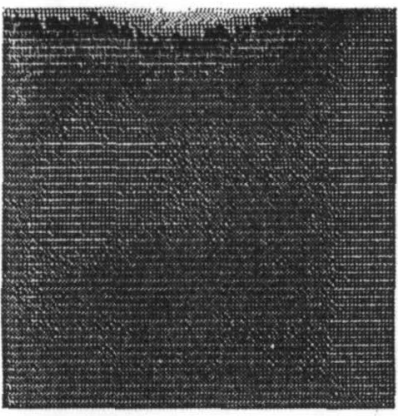

Fig.4 (c) Blue intensity

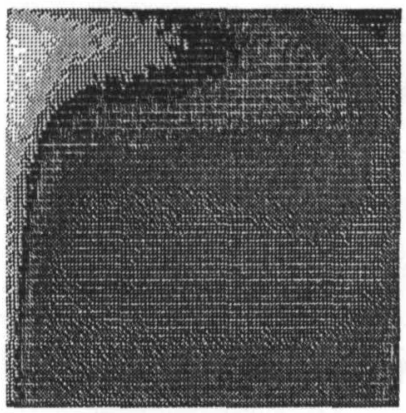

Fig.5 (c) Revised blue intensity

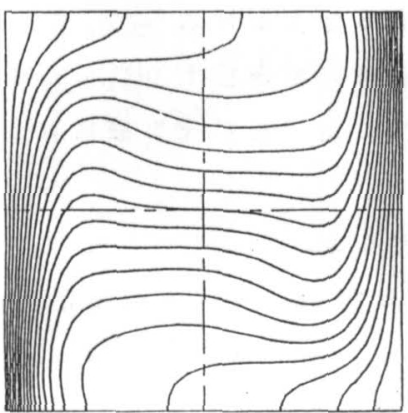

Fig.7 (b) Isotherms hy caiculation 


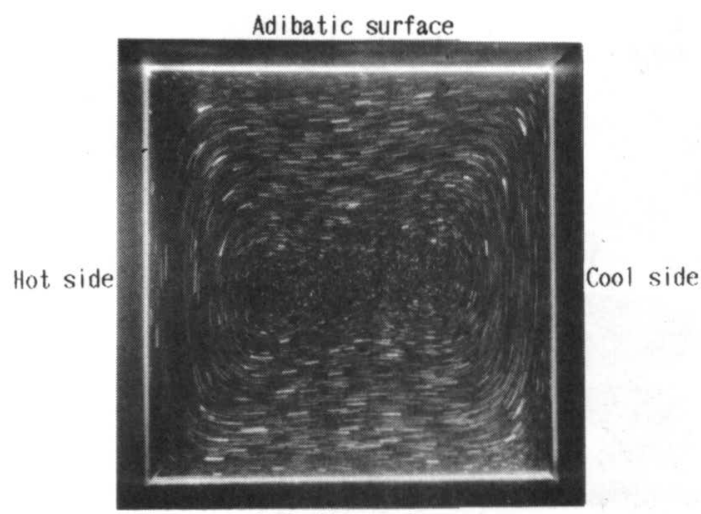

Adibatic surface

Fig.8 (a) Path line by experiment

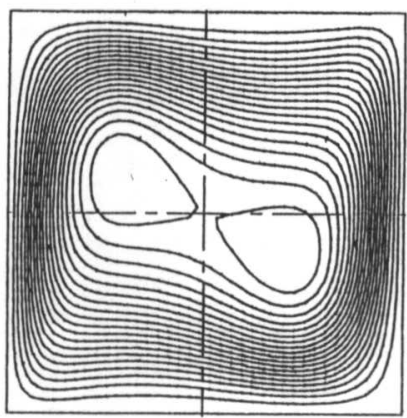

Fig.8 (b) Stream line by calculation

全伝熱の場合に近く、実駼条件が满たされていないためと思われる。しかしながら求めら れた温度分布 (Fig.7 (a)) は、壁付近を含めFig.3の写真とよく一致しており R G B 法は、 断面全体が一挙に定量化できる方法として有効である。

次にバール顔料をトレーサとした粒跡写真をFig.8（a)に、数值解析からの流線をFig.8( b)に示す。渦が二つに分かれ形としては似かよっているが、渦の位置が、実験では左下と 右上に分かれているのに対し、数值解析では、左上と右下に分かれている。この差の原因 としては、シリコン油の物性值（動粘度や密度）の熱依存性が大きことが考えられる。

5. まとめ

シリコン油を流体とした二次元正方形と見なせる密闑空間内自然対流の実験を行ない、 可視化画像処理技術と、実際現象を表現する数值解析モテルについて考察し次の結論を得 た。

(1)液晶粒子法により温度分布を可視化し、それを画像処理することに依って等温度線を示 した。またバール顔料に依って流動バターンを可視化した。

（2）物性值一定、断熱上下壁の条件による数值解と比較して、温度分布及び流動バターンと あ䢖いが制察された。これは、シリコン油の温度による物性值変化が大きいこと、及び意 図的には断熱非加熱とした上下壁か、、実際には壁面に沿って熱伝胖があり、且っ不完全断 熱であることに依る。

本研究を遂行するにあたり、御示唆、御援助を賜った日本原子力研究所、秋野詔夫氏、 並びに功刀資彰氏に感謝致します。

\section{参考文献}

（1）秋野他、流れの可視化、VOL.3、p.40(1983)

(2)功刀他、機論 (B)、VOL.53、p.241(1987)

（3）秋野他、流れの可視化、V0L.7、p.235(1987) 